\title{
Análise geoeconómica da atuação da China no setor das terras raras: Estudo de casos
}

\author{
China's geoeconomic strategy in the rare earth industry: Case studies
}

\author{
Carla Costa* \\ *Instituto Superior de Ciências Sociais e Políticas, Portugal; Email: cguapoc@hotmail.com
}

\begin{abstract}
RESUMO
Este artigo procura, através de dois estudos de caso (Japão e EUA), analisar a atuação geoeconómica da China, enquanto principal país produtor e exportador, no setor das terras raras, elementos minerais considerados de importância crítica para o funcionamento das cadeias de valor de indústrias de alta tecnologia, tecnologias limpas ou defesa. Os dados disponíveis e a análise documental apontam para uma utilização dupla da preponderância chinesa no setor, quer como forma de reorganização industrial e dinamização do crescimento económico, quer como meio de pressão geopolítica sobre os países importadores. Em qualquer dos casos analisados, emerge a necessidade de fortalecer a resiliência das cadeias de valor mundiais, especialmente nos setores considerados estratégicos para a segurança económica e nacional.
\end{abstract}

Palavras-chave: China; Terras raras; Geoeconomia; Cadeias de valor

\section{ABSTRACT}

This paper analyses the essence of China's geoeconomics strategy in the rare earth industry, by analyzing two case studies, Japan, and the USA. China is the leading producer and exporter of rare earth elements, mineral substances that are critical to high technology sectors, clean industries, or defense. Available data suggest that 
China has been using its leading position to promote the development of the country's main industries, but also to achieve geopolitical goals. The Chinese industrial and trade policies have made clear to importing countries the urge to keep global value chains' resilience in strategic sectors for economic and national security.

Keywords: China; Rare Earths; Geoeconomics; Value Chains

\section{Introdução}

Em 2010, um acontecimento, inicialmente pouco valorizado, alertou os principais líderes mundiais para a vulnerabilidade a que os seus sistemas de produção estavam sujeitos, quando dependiam de fornecedores poderosos e potencialmente hostis: a China aumentava drasticamente as restrições e decretava um embargo à exportação de terras raras, na sequência de uma disputa territorial com o Japão, comprometendo o funcionamento de algumas das principais cadeias de valor das grandes potências mundiais. Mais recentemente, em 2019, em plena guerra comercial, o líder chinês, Xi Jinping, alertou os EUA para a possibilidade de a China tomar medidas que condicionassem novamente a exportação das terras raras. Ambos os casos revelam a utilização de instrumentos de cariz eminentemente económico para atingir objetivos geopolíticos, configurando o que vários autores denominam uma atuação geoeconómica, e que tem vindo a assumir uma importância crescente no contexto de uma economia global perigosamente interdependente. Embora sejam utilizadas em muito pequena escala, a essencialidade das terras raras na produção de vários equipamentos em setores considerados estratégicos (defesa, inteligência artificial, tecnologias limpas), confere-lhes uma importância geopolítica desproporcionada, pelo que o acesso aos mesmos se tornou uma questão de segurança económica e nacional para vários países (Stratfor, 2019) (Kalantzakos, 2020).

\section{A (re)emergência da Geoeconomia:}

\section{A importância de uma abordagem geoeconómica}

Os dados empíricos disponíveis e a literatura académica que os analisa têm vindo a demonstrar que a concorrência geopolítica, principalmente no período pós-crise financeira, está a reconfigurar a economia global e a tornar mais intensas as relações de poder e governação (Leonard, 2016). Os efeitos dessa reconfiguração atingem todos os Estados, podendo originar mudanças na balança global de poder e um aumento das tensões (Bergeijk, Putten, Rood, \& Meijnders, 2015), mas incidem de forma mais intensa sobre as economias que são muito dependentes do ambiente internacional. 
Efetivamente, ao longo das últimas três décadas, o mundo mudou: a globalização, a ascensão de grandes economias emergentes, o peso (in)sustentável dos desequilíbrios orçamentais e externos nas economias desenvolvidas, o sucesso das economias mistas de mercado (com empresas privadas e a participação do estado nas denominadas indústrias estratégicas), ou a espionagem cibernética, têm trazido as temáticas de índole económica para o cerne da definição e operacionalização da segurança nacional (Ronis, 2011). Num outro plano, a necessidade de acesso sustentável aos recursos naturais, a sucessão de crises económicas e financeiras, com as consequentes perturbações sobre o funcionamento das economias contemporâneas (desemprego, exclusão social, desigualdades na repartição do rendimento) e novos modelos de relacionamento entre o Estado e o Mercado, são alguns dos condicionantes que conformam a evolução das referidas sociedades. Adicionalmente, e no contexto atual, a emergência da crise pandémica tornou dolorosamente evidente a vulnerabilidade das cadeias de valor em produtos e setores críticos para a segurança nacional.

Em síntese, a segurança de um país é cada vez mais prosseguida não por meios militares, embora estes ainda se revistam de considerável importância, mas recorrendo a uma vasta gama de ativos e instrumentos económicos (Nanto, 2011).

Blackwill e Harris (2016) consideram que se pode definir a geoeconomia como a utilização de instrumentos económicos para promover e defender o interesse nacional, e alcançar objetivos geopolíticos, destacando a forma de perceber como «the effects of other countries economic actions can affect the geopolitical goals of a certain country». (Blackwill \& Harris, 2016, p. 20)

Os autores expõem também alguns dos instrumentos do economic warfare, incluindo embargos comerciais, boicotes, sanções, discriminação por via de tarifas, restrições à importação, subsídios à exportação, manipulação cambial, financiamento para os gastos com investigação e desenvolvimento tecnológico, formação de capital humano, infraestruturas críticas, investimentos estratégicos realizados através do investimento direto feito noutros países; a compra, por parte de governos nacionais, da dívida pública de outros estados congelamento de bens de capital, suspensão de ajuda, uso dos Fundos Soberanos e das State Owned Enterprises (SOE), ou bloqueio no acesso a recursos naturais estratégicos (Blackwill \& Harris, 2016, p. 49). Todos estes instrumentos aumentaram o seu poder de alavancagem no contexto do processo de globalização que sustentou o crescimento da economia mundial desde os anos 1980. No entanto, como refere Leonard (2016, p. 4), a Geoconomia acaba por ser, em simultâneo, a antítese e o grande triunfo da globalização, já que o Estado, 
através do economic statecraft, desempenha um papel preponderante na economia internacional e global. Csurgai segue a mesma linha de pensamento, ao defender que: «Geoeconomics illustrates the strategic interactions between state agencies and various economic sectors to enhance the power position of states in the contemporary international system.» (Csurgai, 2018, p. 41)

A ascensão de grandes e poderosas economias emergentes com modelos socioeconómicos muito afastados das democracias liberais de mercado (sendo, naturalmente, a China o caso mais paradigmático), os choques que afetam os mercados financeiros nos países desenvolvidos ou a disputada corrida pela supremacia tecnológica por parte das maiores potências, voltaram a realçar a importância da ação do Estado (statecraft) para resolver (ou atenuar) os problemas que a hiperglobalização causou. E como todos os países estão fortemente dependentes da economia global para o seu crescimento, a ameaça de se verem excluídos ou limitados no acesso aos benefícios decorrentes do funcionamento daquela constitui um poderoso instrumento, de dissuasão ou incentivo, que os seus rivais poderão utilizar. Fatores como a dimensão das economias dos EUA e da China, a posição determinante que têm na gestão das cadeias de valor, o mercado que oferecem às exportações dos outros, os recursos naturais que detêm, fazem aumentar a vulnerabilidade geoeconómica dos restantes países ao economic statecraft que qualquer um dos dois queira exercer, sob a forma de incentivo ou coerção.

Tais estratégias permitem aos países exercer influência geopolítica através da dependência económica. Também temos visto países recorrer a medidas para controlar o acesso a recursos importantes de modo a fortalecer a sua posição geopolítica. Estas medidas potenciais para alavancar o poder sobre outros países através dos laços económicos estão a tornar-se uma parte cada vez mais importante e explícita do pensamento em matéria de política externa.

O caso das terras raras, que nos propomos analisar neste artigo, é um exemplo claro, já que se tem assistido, a nível global, a uma disputa para assegurar o acesso ininterrupto aos denominados materiais críticos, nomeadamente aqueles que são essenciais à produção nos setores da alta tecnologia, energias renováveis ou aplicações para a defesa. Dada a dependência global destes componentes, a possibilidade de haver escassez ou disrupção no abastecimento desperta grandes preocupações entre os países dependentes. Neste sentido, vários países definiram o que entendem por minerais críticos para, precisamente, poderem pôr em prática medidas que assegurem a continuidade no fornecimento dos mesmos. Como refere Nakano (2021), a confluência de vários fatores (concorrência crescente no acesso aos minerais críticos e à produção de equipamentos de energias limpas, a fragilidade das cadeias glo- 
bais de valor e a proeminência da China), levou vários países a rever o estado das respetivas cadeias de valor de minerais críticos. A autora cita os casos da Índia (para desenvolver o seu programa de inovação tecnológica na indústria, o Make in India), da Austrália (que visa tornar-se líder mundial na exploração, produção e processamento de materiais críticos, com recurso ao reforço do investimento e da inovação), e debruça-se especificamente sobre as iniciativas norte-americanas, japonesas e da União Europeia, para evidenciar como estes países foram atualizando as respetivas estratégias, ampliando o leque de instrumentos de política económica ou desenhando novos planos de ação para garantir a sustentabilidade e resiliência das cadeias de valor. Por exemplo, os EUA incluem as terras raras na lista de minerais críticos (ou de importância crítica), que preenchem os seguintes critérios, de acordo com a Ordem Executiva 13817:

1. Ser um mineral, combustível ou não, essencial à segurança económica e nacional dos EUA;

2. Pertencer a uma cadeia de valor que seja vulnerável a disrupções no fornecimento;

3. Desempenhar uma função essencial na produção de um determinado produto, cuja inexistência ou escassez poderia ter consequências significativas na economia ou segurança nacionais.

Kalantzakos (2020) destaca a dependência global destes inputs, por parte dos países mais avançados, o que torna a eventual escassez dos mesmos uma preocupação crescente, especialmente em determinadas indústrias. Neste contexto, a competição geopolítica assume maior protagonismo, já que o fornecimento desses minerais pode ser interrompido por várias razões, tais como os embargos ou conflitos comerciais, ou, mais recentemente, a crise pandémica, que teve um efeito devastador em várias cadeias de valor, realçando a importância da diversificação dos fornecedores para fortalecer a resiliência dessas cadeias.

Assim, é de salientar a posição da China, como maior produtor de terras raras (a nível do processamento das mesmas), com uma quota de quase 60\%, e detentor de 1/3 das reservas mundiais das mesmas (Adamas Intelligence, 2019). Para além de poder exercer o seu poder de mercado e condicionar outros países na tomada de posições em matérias do seu interesse, as iniciativas recentes desenvolvidas pela China, como a Belt and Road Initiative (BRI) ou o programa de desenvolvimento tecnológico Made in China 2025 (e também o mais recente Plano Quinquenal, entre 2021 e 2025) dependem fortemente da 
incorporação de terras raras, pelo que se antevê que a China envide todos os esforços no sentido de assegurar a disponibilidade constante e em quantidade suficiente daqueles, o que pode significar uma redução das vendas ao exterior, comprometendo a cadeia de valor de outros países.

\section{Definição e importância das terras raras}

Existe na natureza um conjunto de 17 elementos que constituem as denominadas terras raras: o escândio, o ítrio e 15 lantanídeos. Divididas entre terras raras leves (LREE), mais abundantes, e pesadas (HREE), as suas propriedades magnéticas e luminescentes fazem desses componentes essenciais para as tecnologias digitais e de baixa intensidade carbónica, o que os lhes confere uma importância estratégica para o desenvolvimento das tecnologias associa-

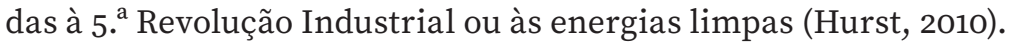

Por outro lado, a sua estrutura de produção e de mercado, no contexto do funcionamento da economia mundial, tem vindo a adquirir cada vez maior importância porque se trata de uma cadeia de valor em que, da fase da mineração à do processamento e utilização em produtos finais, a dominância da China é avassaladora, fazendo com que as terras raras tenham sido classificadas como matérias-primas críticas em vários países importadores.

Ao contrário do que o nome indica, as terras raras são elementos relativamente abundantes na crosta terrestre, sendo o cério, por exemplo, tão abundante como o cobre, o neodímio e o ítrio mais abundantes que o chumbo, o samário e o praseodímio mais abundantes que o estanho (Adamas Intelligence, 2019). O problema é que, dadas as suas propriedades geoquímicas, estes elementos estão muito dispersos, o que significa que, em grande parte dos casos, não estão suficientemente concentrados para ser viável, do ponto de vista económico, a sua mineração. Por outro lado, um dos principais riscos relacionados com a exploração das terras raras prende-se com uma vulnerabilidade estratégica. As terras raras são vitais para inúmeras tecnologias, em vários setores críticos para o desenvolvimento e a segurança dos Estados, desde a defesa às tecnologias de combate às alterações climáticas, e à promoção das energias limpas. Tornam-se valiosas porque têm propriedades que tornam a sua substituição muito difícil; no entanto, a sua exploração acaba por não ser rentável, porque, embora fundamentais, são utilizadas em muito pequenas proporções. A dimensão do mercado de terras raras é bastante reduzida, sendo que o valor total de não ultrapassa os 9 mil milhões de dólares. No entanto, a sua utilização em produtos de alta tecnologia tem crescido exponencialmente ao longo do tempo, pelo que assumem uma importância crítica para produtos que valem 7 biliões de dólares numa economia global de valor 
equivalente a 75 biliões (Ganguli \& Cook, 2018). Para além disso, as devastadoras consequências ambientais associadas à sua exploração fazem que poucos países tenham incentivo a desenvolver os respetivos procedimentos.

Neste contexto, a cadeia de valor dos minerais e materiais indispensáveis para as tecnologias de energia limpa tornou-se numa questão estratégica, não só porque determina o ritmo do avanço tecnológico naquelas áreas, mas porque a tecnologia associada às energias limpas se tornou uma espécie de última fronteira para as rivalidades geoeconómicas entre a China e os EUA, Japão ou União Europeia.

Como podemos verificar na Figura 1 e na Tabela 1, a importância estratégica das terras raras deriva do facto dos 17 elementos que as compõem serem essenciais para as modernas tecnologias avançadas, não só em várias áreas

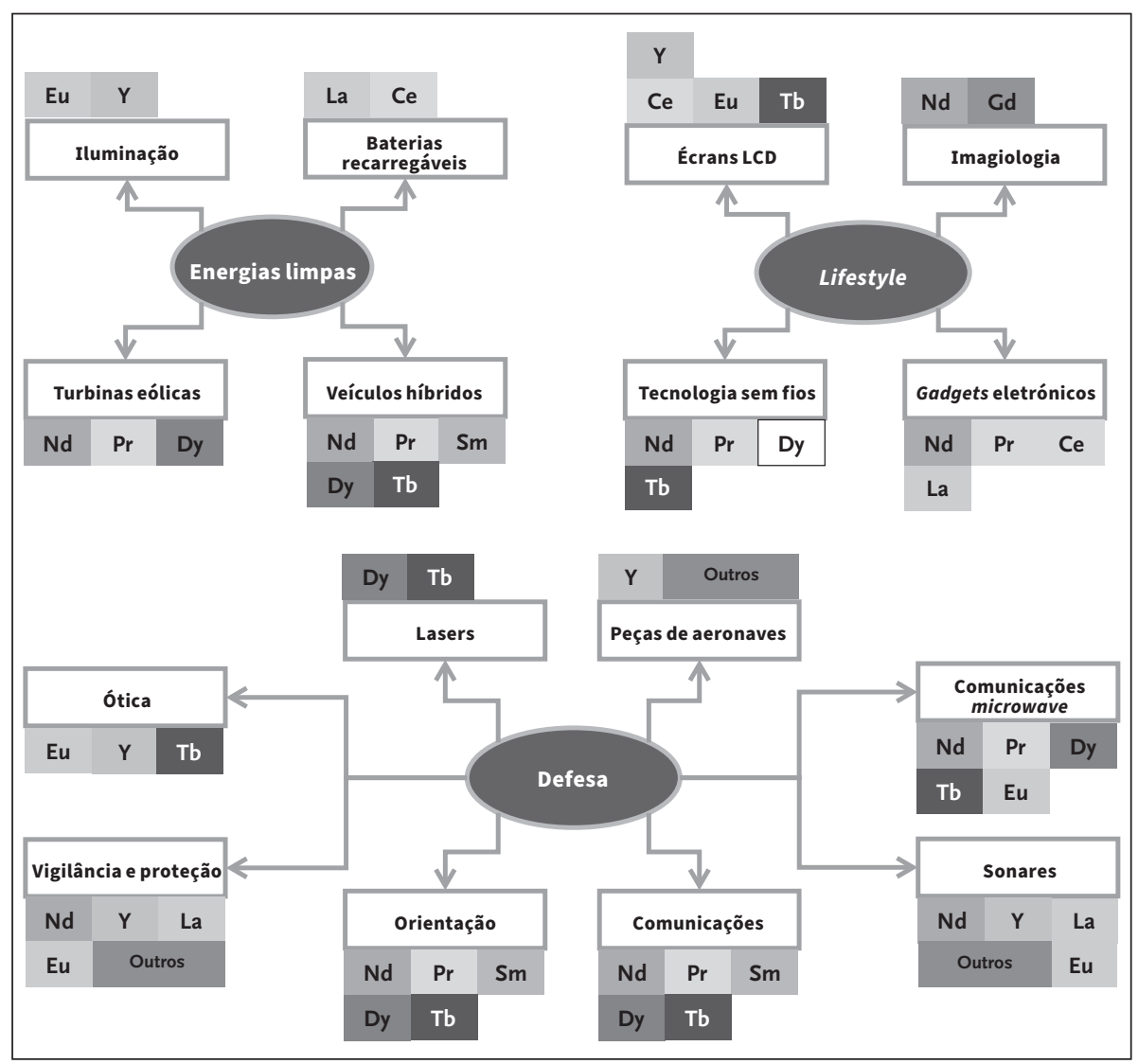

\section{FIGURA 1}

Presença das terras raras em setores de atividade Fonte: UNCTAD, 2014. 
críticas para o crescimento económico, mas também para a segurança nacional: comunicações, defesa, medicina, setor automóvel, energias limpas. Assim, vamos encontrar a presença destes elementos em smartphones, sistemas de navegação (GPS), turbinas eólicas, painéis fotovoltaicos, veículos elétricos, imagiologia (equipamento para ressonâncias magnéticas, tomografias computorizadas, ventiladores, tratamento para o cancro); drones e armamento sofisticado. Embora sejam utilizados em quantidades ínfimas, as suas propriedades físico-químicas tornam esses elementos indispensáveis para a produção nos vários setores acima referidos. A título de exemplo, refiram-se os EUA, que usam 5\% das terras raras existentes em aplicações no setor da defesa (Smith, 2012), como mísseis teleguiados ou motores de aviões, entre outros.

\section{TABELA 1}

Terras raras e respetivas aplicações

\begin{tabular}{|c|c|}
\hline TERRA RARA & APLICAÇÃO \\
\hline Ítrio & Cerâmica, ligas de metal \\
\hline Lantânio & Baterias, catalisadores para refinação de petróleo \\
\hline Cério & Catalisadores, polimento de vidros, ligas de metal \\
\hline Praseodímio & Imãs de grande potência, pigmentos de cerâmica \\
\hline Neodímio & Imãs de grande potência \\
\hline Promécio & Fontes de radiação beta \\
\hline Samário & Imãs de alta temperatura \\
\hline Európio & Iluminação fluorescente \\
\hline Gadolínio & Agentes de contraste para ressonância magnética \\
\hline Térbio & Imãs de alta potência \\
\hline Disprósio & Imãs de alta potência e temperatura, lasers \\
\hline Hólmio & Imãs de altíssima temperatura \\
\hline Érbio & Lasers, corantes de vidro \\
\hline Túlio & Materiais magnéticos de cerâmica \\
\hline Itérbio & Tecnologia de fibra ótica, painéis solares \\
\hline Lutécio & Tomografia por emissão de positrões (PET scanner) \\
\hline
\end{tabular}

Fonte: UNCTAD e Lynas. 


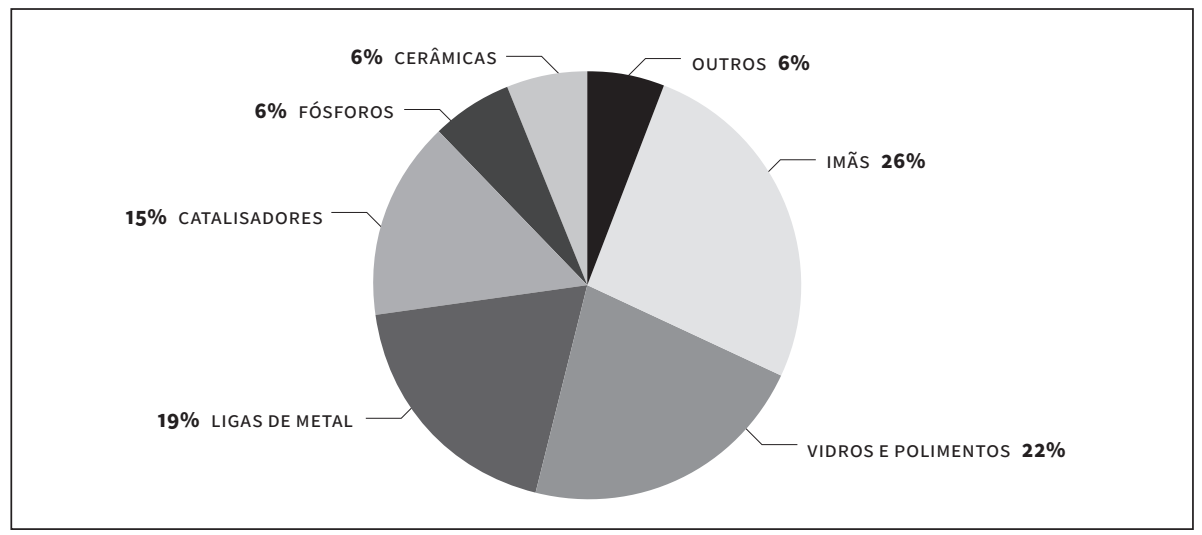

\section{GRÁFICO 1}

Principais aplicações das terras raras

Fonte: US Geological Survey.

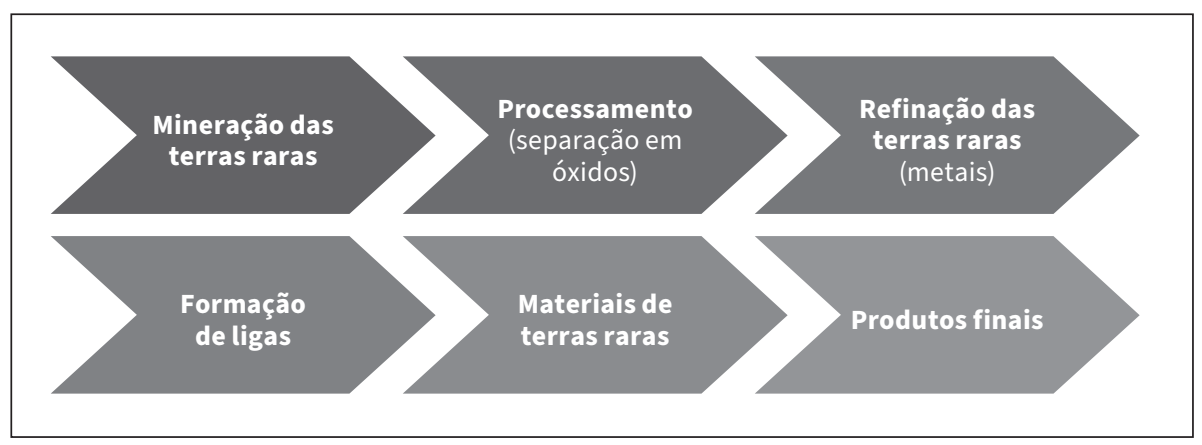

\section{FIGURA 2}

Cadeia de valor das terras raras

Fonte: Adaptado de Hurst (2020).

Como também podemos testemunhar no Gráfico 1, a nível global, as principais aplicações das terras raras centram-se nos vidros e polimentos, ligas de metal e catalisadores, que serão, posteriormente, utilizados nos produtos finais acima referidos.

No entanto, as consequências ambientais da mineração e processamento das terras raras são devastadoras, como demonstra o caso da China, que analisaremos posteriormente, dada a especificidade dos processos de separação dos elementos.

Como refere Hurst, é muito mais difícil e oneroso extrair e processar as terras raras do que o ouro, por exemplo. Observando a Figura 2, verifica-se 
que a cadeia de valor das terras raras consiste em seis etapas fundamentais: mineração; separação; refinação; formação de ligas; materiais, integração na produção de produtos finais de alto valor acrescentado. A primeira etapa consiste na escavação do minério do solo; a segunda fase na separação do minério em óxidos individuais de terras raras; a terceira fase implica a refinação desses óxidos em metais, que podem ser secos, armazenados e despachados para processamento em metais. A quarta fase traduz-se na formação de ligas a partir desses metais; a quinta fase na produção de materiais (imãs, por exemplo). A sexta fase consiste na integração desses materiais nos produtos finais, de maior valor acrescentado (Hurst, 2010).

\section{A situação atual das terras raras}

A procura por terras raras está a subir, de forma acentuada, dada a sua utilização, nomeadamente nas aplicações de energias renováveis (veículos elétricos e híbridos) e indústrias de alta tecnologia, onde o neodímio e o praseodímio, principalmente, são fundamentais. Em 2020, segundo dados do US Geological Survey (2021), a produção de metal de terras raras cresceu novamente, para atingir 240.000 toneladas métricas, um aumento de $9 \%$ em relação a 2019, e de $26 \%$ face a 2018.

Entre os principais atores (produção e reservas), destaca-se claramente a China, que tem dominado a produção de terras raras desde há vários anos. Em 2020, o seu output doméstico foi de 140.000 toneladas (um aumento de $6 \%$ face a 2019), o que representa quase 60\% da produção global (Tabela 2).

Apesar da dominância da China, cabe dizer que os produtores chineses têm de obedecer a um sistema de quotas para a produção de terras raras, que constitui uma resposta aos problemas que o país enfrenta com a mineração ilegal, desde há muito tempo. Ao longo da última década, têm vindo a ser tomadas medidas para resolver o problema, incluindo o fecho de minas ilegais ou que não cumpram os critérios ambientais, e limitando a produção. No início deste século, existiam seis empresas mineradoras (Northern Rare Earth, Southern Rare Earth, Chinalco, Xiamen Tungsten, Minmetals Rare Earth, Guangdong Rare Earths), de capitais públicos, que resultaram da reestruturação do sector (aquisições de outras companhias e processos de fusão), e que estão encarregues da indústria chinesa de terras raras, permitindo à China um forte controlo sobre a produção. No entanto, o processo de reestruturação continuou, tendo a China anunciado, em Outubro de 2021, que irá proceder à fusão de três empresas produtoras de terras raras, criando uma State Owned Enterprise (SOE) que irá deter cerca de $70 \%$ da quota de produção doméstica de metais 
essenciais à produção de produtos de alta tecnologia, procurando o controlo da totalidade da cadeia de valor, incluindo as exportações, antecipando o prolongamento das tensões com o governo dos Estados Unidos (Tabeta, 2021).

No ranking dos maiores produtores, aparecem os EUA, em segundo lugar, com uma produção total de 38.000 toneladas, em 2020, um aumento de $36 \%$ face a 2019 , representando $16 \%$ da produção global e $27 \%$ da produção da China. O fornecimento de terras raras dos EUA vem da mina de Mountain Pass, na Califórnia, que regressou à produção em 2018, depois de estar parada desde 2015. A referida mina era anteriormente gerida pela empresa Molycorp, sendo depois comprada pela MP Mine Operations, agora MP Materials (registe-se que uma outra empresa chinesa, com participação do Estado chinês, a Shenghe Resources Holding Co. Ltd., tem uma quota de $8 \%$ no capital da MP Materials). Os EUA são um grande importador de terras raras, e as tensões com a China levaram os EUA a considerar as terras raras como minerais críticos, como vimos em secção supra.

O terceiro maior produtor foi Myanmar, que minerou 30.000 toneladas em 2020, e que tem uma relação próxima com a China, tendo fornecido 50\% das necessidades chinesas de terras raras pesadas.

TABELA 2

Produção e reservas de terras raras

\begin{tabular}{|c|c|c|c|c|}
\hline Países & PRODUÇÃO & $\%$ & RESERVAS & $\%$ \\
\hline China & 140,00 & 58,3 & 44000000 & 36,7 \\
\hline EUA & 38,00 & 15,8 & 1500000 & 1,3 \\
\hline Myanmar & 30,00 & 12,5 & - & - \\
\hline Austrália & 17,00 & 7,1 & 4100000 & 3,4 \\
\hline Madagascar & 8,00 & 3,3 & - & - \\
\hline Índia & 3,00 & 1,3 & 6900000 & 5,8 \\
\hline Rússia & 2,70 & 1,1 & 12000000 & 10,0 \\
\hline Tailândia & 2,00 & 0,8 & - & - \\
\hline Vietname & 1,00 & 0,4 & 22000000 & 18,3 \\
\hline Brasil & 1,00 & 0,4 & 21000000 & 17,5 \\
\hline Total & 240,00 & 100,0 & 120000000 & 100,0 \\
\hline
\end{tabular}

Fonte: US Geological Survey. 


\section{O domínio da China na produção de terras raras: o "petróleo" do império do meio}

Como refere Wübbeke (2013, p. 385) a modernização económica da China é a história de uma escalada na exploração de recursos. Se nos anos 1980, os EUA eram o principal produtor mundial de terras raras, a situação conheceu alterações significativas na década seguinte (Seaman, 2019). A importância da China, principalmente em termos de produção (processamento) emergiu, e consolidou-se, em resultado de várias medidas: a orientação da política industrial e de desenvolvimento tecnológico, as mudanças políticas noutras regiões produtoras e os efeitos da globalização, com a liberalização dos movimentos de comércio e capitais (Shen, Moomy, \& Eggert, 2020). Neste contexto, a China aproveitou para alavancar o seu desenvolvimento tecnológico em vários setores, desde o espaço, defesa ou energia.

O reduzido custo da mão de obra e da energia, os financiamentos públicos aos esforços de investigação e desenvolvimento tecnológico no setor e a liberal legislação no domínio da proteção do ambiente, permitiram à China manter os custos de produção substancialmente abaixo dos seus concorrentes, originando, nomeadamente no caso dos EUA, a deslocalização das respetivas empresas para a China (Seaman, 2019). Por seu lado, as empresas chinesas também puderam localizar-se em países estrangeiros, onde foi possível consolidar o know how tecnológico, que foi fundamental para permitir à China tornar-se o produtor dominante a montante na cadeira de valor, nomeadamente nos óxidos de terras raras, onde já tinha uma posição de grande protagonismo, mas, principalmente, a jusante da cadeia de valor, na produção de bens finais, como imãs ou catalisadores. Hurst relata o caso dos imãs $N d F e B$, onde se verificou a aquisição da empresa Magnequench da General Motors, nos EUA, no final dos anos 1990, por parte de uma empresa chinesa, e a consequente deslocalização da empresa para a China no início de $2000^{[1]}$; outro caso é do fabricante japonês Hitachi Metals, de imãs high end, que estabeleceu uma joint venture com a empresa chinesa Zhong Ke San Huan, antevendo o crescimento da procura dirigida aos referidos imãs. (Hurst, 2010). A empresa chinesa era a principal fabricante dos referidos imãs $N d F e B$, indispensáveis para a produção de veículos elétricos, cuja procura disparou no mundo inteiro por pressões ambientais. Dadas as restrições vigentes, a Hitachi Metals decidiu estabelecer fábricas na China, em joint venture com a Zhong Ke San Huan, de modo a expandir o seu negócio à escala global (Hitachi Metals Ltd, 2016).

1. Este caso será desenvolvido em secção posterior. 
No entanto, e como referido acima, o domínio da mineração e processamento das terras raras por parte da China não foi algo espontâneo, mas antes construído ao longo de todo o século xx. Em 1992, o histórico líder chinês, Deng Xiaoping, lançou as bases para um novo projeto geoeconómico chinês, quando afirmou que se o Médio Oriente tinha o petróleo, a China tinha as terras raras. E, desde essa data, foi lançado um vasto programa de desenvolvimento de extração e processamento desses minerais ao longo de 40 anos, que fez com que a China detenha hoje entre 80 e 90\% da mineração, processamento e produção dos minerais e dos seus produtos finais a nível global (USGS, 2021).

Mas todo o processo começa muito antes, quando, em 1927, são descobertos depósitos de terras raras na região autónoma da Mongólia Interior, em Bayan Obo.

Mais tarde, nos anos 1940, por altura da criação da República Popular da China, embora a China já detivesse uma grande abundância de recursos de terras raras, a respetiva indústria era praticamente inexistente (Bryant, 2015).

Em 1950, foi construída uma mina em Bayan Obo, uma região geologicamente muito rica e complexa, que acolhe mais de $80 \%$ das reservas de terras raras existentes na China, começando desde essa data a recuperação de terras raras no âmbito do processo de produção do ferro e do aço. Essa mineração tornou-se uma prioridade política, já que, para além de a região ter estado, desde os anos 1930, muito sujeita a ataques por parte do Japão, dada precisamente a sua riqueza geológica, em ferro, terras raras e nióbio, foi considerada um eixo estratégico do desenvolvimento económico e soberania da China em minerais críticos para a produção de bens essenciais, pelo que a sua exploração poderia conferir à China uma posição dominante que reforçaria a dependência de outros países (Wubekke, Rare earth elements in China: policies and narratives of reinventing an industry, 2013) (Higgins, 2015). Assim, para além das características geológicas, assume-se uma componente geoeconómica e geopolítica muito importante no desenvolvimento de todo o projeto (Mancheri, Sundaresan, \& Chandrashekar, 2013).

Neste contexto, foram feitos investimentos significativos na inovação e desenvolvimento tecnológico no setor, tendo mesmo sido criado um poderoso instituto de investigação perto daquela mina nos anos 1960. O desenvolvimento da escala de mineração e produção foi imediato, não obstante o impacto ambiental e sanitário, nunca testemunhado. A mina recebeu grandes somas de investimento soviético, planeamento e ajuda técnica ao longo dos anos 1950, tendo vindo a tornar-se a capital mundial das terras raras (Wubekke, 2015). Também nos anos 1950, foi criada em Baotou, uma grande empresa destinada à refinação do ferro e do aço, a Baogang - Iron and Steel Obo Iron Company, que 
vai aprovisionar-se de matérias-primas à mina de Bayan Obo. A aposta na investigação científica, através de robustos programas governamentais como os Planos 863 e 973, reforçaram o poder económico, e geopolítico, chinês, no mercado mundial de terras raras (Bryant, 2015).

Autoproclamada "Cidade das Terras Raras", Bayan Obo é hoje o maior depósito mineral do mundo desses elementos, representando $45 \%$ da produção mundial em 2019 (Global Atlas of Environmental Justice, 2020). Depois de mais de oito décadas de exploração, tinham sido descobertas terras raras em 21 províncias e regiões autónomas chinesas (ver Figura 2): Fujian, Gansu, Guangdong, Guangxi, Guizhou, Hainan, Henan, Hubei, Hunan, Jiangxi, Jilin, Liaoning, Nei Mongol (Inner Mongolia), Qinghai, Shaanxi, Shandong, Shanxi, Sichuan, Xinjiang, Yunnan e Zhejiang (Tse, 2011). É de realçar, no entanto, o peso de três províncias, que representam 90\% do total: Inner Mongolia (53,3\%), Sichuan (26\%) e Jiangxi (9,6\%) (UNCTAD, 2014).

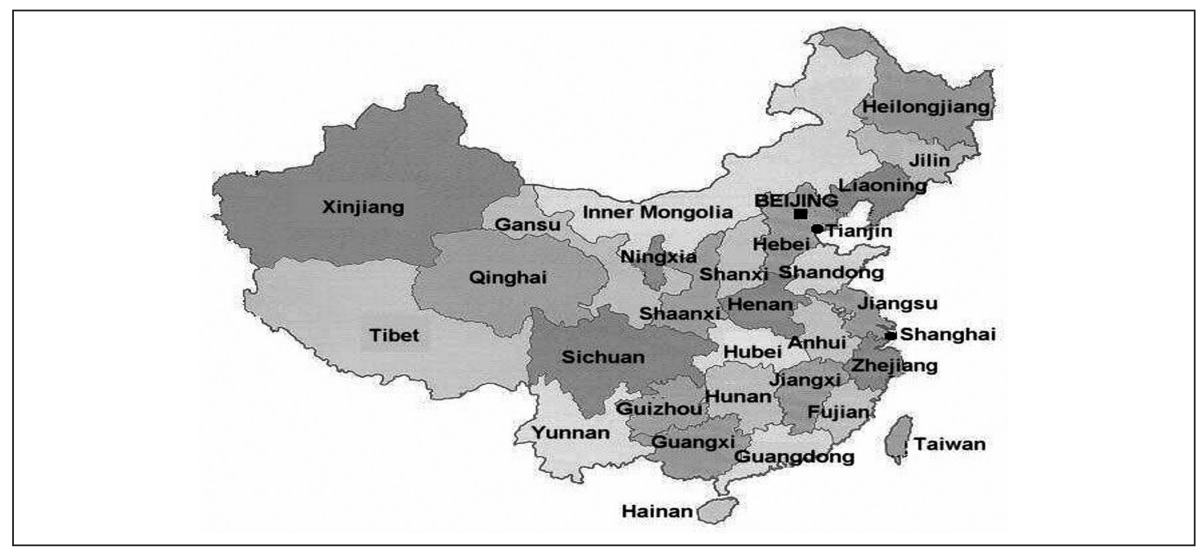

\section{FIGURA 3}

Mapa da China (Províncias e Regiões Autónomas)

Fonte: Instituto Confúcio - Brasil.

Ao longo da década de 1980, como se pode ver no Gráfico 2, a China tornou-se um dos maiores produtores do mundo, até que acabou por ultrapassar os EUA, primeiro produtor mundial na altura, através da sua mina de Mountain Pass, na Califórnia.

Ao longo dos anos 1990, devido ao aumento de produção e exportação chinesas, os preços caíram drasticamente, levando à falência de muitas empresas e ao encurtamento das cadeiras de valor (Kalantzakos, China and the 
Geopolitics of the Rare Earths, 2018). No início da década, em 1990, o governo chinês declarou as terras raras como minerais estratégicos e protegidos, consagrando a perceção de que a China tinha do seu potencial neste domínio. Tal permitia às empresas chinesas adquirir know how estrangeiro, enquanto afastava a concorrência externa da cadeia de valor (CSIS, 2021).

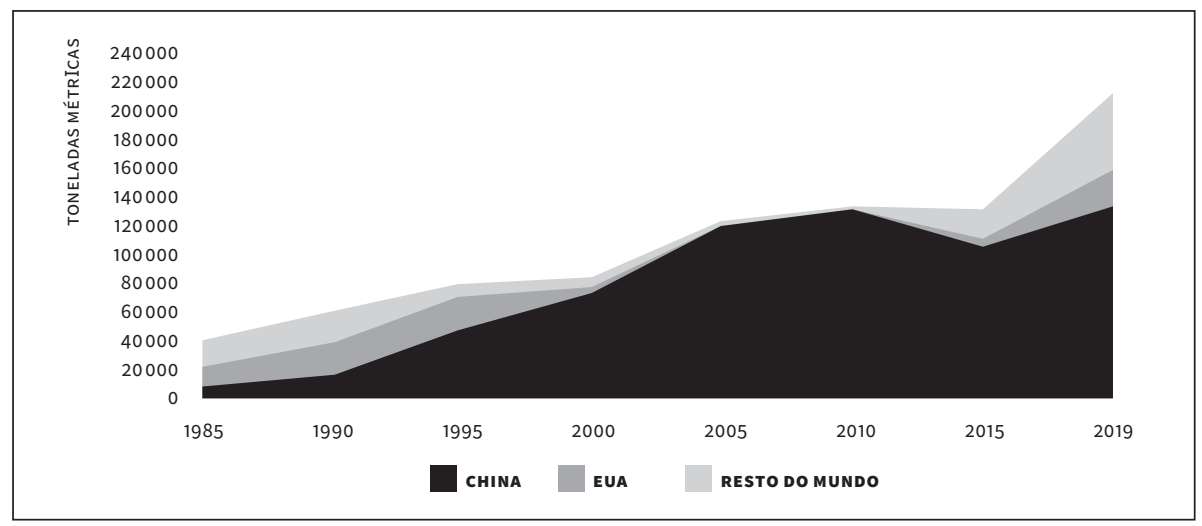

\section{GRÁFICO 2}

Produção (mineração) de terras raras

Fonte: US Geological Service.

Seguiu-se um conjunto de iniciativas, que previam o aumento de um controlo centralizado sobre a indústria, visando o upgrade das empresas chinesas na cadeia de valor. Para tal, a China procurava atrair empresas estrangeiras com o know how mais avançado no setor. A classificação das terras raras como minerais estratégicos conferia à China uma ampla margem de manobra, para centralizar o funcionamento das cadeias de valor (principalmente nas fases de maior valor acrescentado) no país. Por exemplo, os investidores estrangeiros só podiam atuar no processo de fundição e separação das terras raras desde que estivessem associados em joint ventures com empresas chinesas (sujeitas à aprovação da Comissão de Desenvolvimento e Planeamento do Estado chinês) (Kalantzakos, China and the Geopolitics of the Rare Earths, 2018).

E em 1992, numa visita ao distrito de Baotou, na Mongólia Interior, onde se situa a mina de Bayan Obo, Deng terá proferido as palavras que viriam a tornar-se ainda mais determinantes para a exploração de terras raras:

The Middle East has its oil, China has rare earth: China's rare earth deposits account for 80 percent of identified global reserves, you can compare the status of these reserves to that of oil in the Middle East: it is of extremely important strategic 
significance; we must be sure to handle the rare earth issue properly and make the fullest use of our country's advantage in rare earth resources. (Uren, 2019)

Esta abordagem "mercantilista” chinesa às terras raras foi reforçada pelo sucessor de Deng Xiaoping, Jiang Zemin, em 1999, numa outra visita a Baodou. À medida que a capacidade de mineração da China aumentava, os produtores de terras raras noutros países começaram a deslocalizar a produção para a China, para tirar partido dos baixos custos do trabalho e da pouca exigência em matéria de proteção ambiental.

Uma breve análise das políticas chinesas ao longo do tempo fornece uma visão bastante clara das prioridades do Estado chinês. Assim, entre 1975 e 1990, o grande objetivo era a promoção das atividades a montante da cadeia de valor para desenvolver a produção com destino à exportação, com o propósito de encorajar a indústria nascente de mineração de terras raras. Assumia-se que o consumo doméstico não era suficiente para tal, pelo que se incentivava à exportação, nomeadamente através de incentivos fiscais às empresas exportadoras (Shen, Moomy, \& Eggert, 2020). No período seguinte, ao longo da década de 1990, os problemas associados ao crescimento do setor manifestaram-se de forma dramática, com a redução dos preços mundiais, o aumento da produção ilegal e os problemas ambientais. Neste contexto, o governo chinês implementou um conjunto de medidas muito restritivas, que passaram por fortes restrições ao investimento estrangeiro, especialmente na fase a jusante, sendo todos os projetos analisados e aprovados por gabinetes específicos ligados às terras raras, e com severas limitações de acesso às atividades, também visando a proteção ambiental, a preservação de recursos e os problemas derivados do elevado volume de mineração ilegal. As licenças de exploração e mineração foram suspensas, e as empresas estrangeiras só podiam atuar desde que inseridas em joint ventures com empresas chinesas. Todas estas medidas foram enquadradas com a decisão de considerar as terras raras como minerais de importância estratégica para a segurança económica e nacional chinesas, pelo que o governo central assumia a regulação de todas as etapas da cadeia de valor. Entre 1999 e 2009 prosseguiu a rigorosa política de restrições à produção e exportações, ao mesmo tempo que se promoviam as atividades nas fases a jusante da cadeia de valor. A segunda década do século XXI trouxe novas restrições e disputas no seio da Organização Mundial de Comércio motivadas pela política industrial e comercial chinesas no setor das terras raras (Kalantzakos, 2018) (Tse, 2011), uma vez que se trata de um setor de oferta inelástica (não é fácil iniciar ou aumentar a produção no curto prazo para responder a este tipo de choques) (Seaman, 2019). 
Efetivamente, na sequência das medidas tomadas por Deng Xiaoping, em 2010, a China controlava mais de $90 \%$ da mineração das terras raras. E o resto do mundo ficou apavorado, quando, nesse ano, a China restringiu a exportação. Se desde o final dos anos 1990 que a China impunha restrições à exportação de terras raras, especialmente das fases a jusante da cadeia de valor, em 2010 procedeu a um corte abrupto nas quotas de exportação, quase $40 \%$, fazendo disparar os preços de vários elementos: o preço médio da importação de terras raras passou de 9.461 dólares por tonelada métrica, em 2009, para quase 67.000 dólares, em 2011 (CSIS, 2021), deixando muitas empresas nos EUA, Japão e Europa (principais clientes) em situação delicada. A evolução dos preços é significativa, como se pode verificar no Gráfico 3.

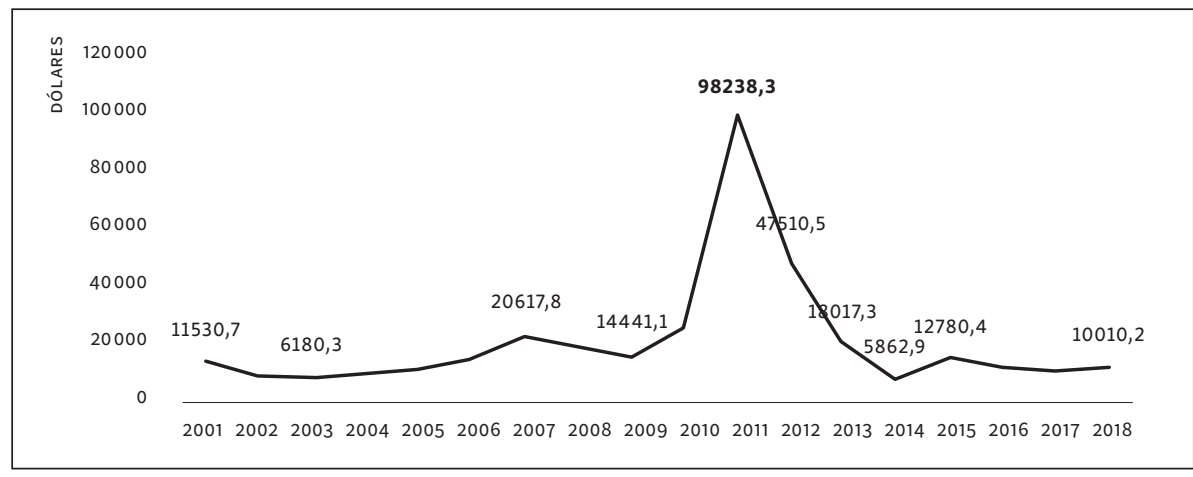

\section{GRÁFICO 3}

Evolução de preços dos metais de terras raras

Fonte: US Comtrade e CSIS.

Apesar das razões oficiais invocadas assentarem na necessidade de travar a degradação ambiental, a postura chinesa alertou vários países, nos EUA e na Europa, de que a China poderia no futuro usar a sua dominância em matérias-primas de importância fundamental para punir os seus rivais. As políticas seguidas por Pequim geraram frutos, já que as empresas locais, com o mercado reservado e fortemente condicionado a empresas estrangeiras, acabaram por dominar a produção global.

$\mathrm{O}$ ano de 2010 foi também o ano do embargo à exportação de terras raras para o Japão, que muitos associaram a disputas territoriais entre os dois países, especificamente ao caso das Ilhas Senkaku.

Mas os principais importadores reagiram, e, em 2012, os EUA, a União Europeia e o Japão apresentaram várias queixas junto da Organização Mun- 
dial de Comércio (OMC), contra a concorrência desleal a favor das empresas chinesas $^{[2]}$. A OMC decidiu a favor dos queixosos, pelo que a China acabou por retirar as quotas de exportação em 2015. Também a partir de 2011, vários países detentores de recursos (EUA, Austrália, Rússia) começaram a aumentar a produção, fazendo baixar a quota da China para pouco mais de $80 \%$. Ao longo deste período, o governo chinês continuou a publicar legislação com o objetivo de reorganizar o setor (incluindo a reestruturação empresarial), privilegiando, essencialmente, a proteção ambiental e o desenvolvimento tecnológico nos segmentos a montante da cadeia de valor.

Ainda em 2010, é publicado o Livro Branco sobre as Terras Raras, Situation and Policies of China's Rare Earth Industry, onde o governo chinês justifica as restrições à exportação e defende a posição da China no seio da OMC, face aos processos movidos pelos EUA, União Europeia e Japão. Entre as principais medidas propostas, é equacionado um propósito de dominar um sistema industrial completo, da mineração à utilização final, incluindo as exportações. São definidos objetivos integrados e ambiciosos, que passam pela reestruturação do setor, no sentido de permitir uma maior concentração empresarial, associada ao fecho de minas, por razões ambientais e para evitar os negócios ilegais. É assumido que a China pretende tornar-se um hub de inovação no setor até 2020, e uma potência científica global até 2050, sendo sempre evidenciadas as preocupações de ordem ambiental. É defendido um sistema tecnológico que assenta num modelo top down, com um forte dirigismo estatal dos programas de ciência e tecnologia, para dinamizar o desenvolvimento tecnológico em áreas de importância estratégica, com as empresas estatais a promoverem a ligação entre os institutos de pesquisa e as empresas (Information Office of the State Council - PRC, 2010).

É também de realçar o facto de em 2011 as terras raras terem subido mais uma etapa na sua importância estratégica para o estado chinês, tendo sido colocadas formalmente sob a alçada do poderoso Ministério da Indústria e Tecnologias da Informação, o arquiteto da política industrial chinesa (Mancheri, Sundaresan, \& Chandrashekar, 2013).

No entanto, nos anos mais recentes as preocupações intensificaram-se, pois a China continuou a investir, não apenas nas terras raras, mas em minas situadas em países terceiros, cujos produtos são depois enviados para a China para processamento: para além das terras raras, a China processa $72 \%$ do cobalto mundial e 61\% do lítio. Em 2019, a China produzia quase 90\% de metais, ligas de metais e imãs de terras raras (CSIS, 2021).

2. Ver secção seguinte. 


\section{As terras raras como trunfo geoeconómico na disputa em torno das Ilhas Diaoyu/Senkaku}

Em 2010, não foram apenas as quotas de exportação a desestabilizar o mercado das terras raras, agravando-se a situação com a imposição de um embargo às exportações chinesas destinadas ao Japão, comprometendo o funcionamento das principais cadeias de valor nipónicas e fazendo recrudescer as preocupações com a utilização das terras raras para fins geopolíticos. As relações entre a China e o Japão sofreram um abalo significativo, com os dois governos a acusarem-se mutuamente de agressão e comportamento incorreto.

De acordo com vários autores (Overland, 2019) (Lovins, 2017) (Wübbeke, 2013), a atitude chinesa insere-se no contexto que levou à tomada de várias iniciativas de política industrial e comercial para reorganizar o setor e aumentar e mitigar a devastação ambiental, como vimos na secção supra. Mas, para outros (Blackwill \& Harris, 2016) (Kalantzakos, 2020), o que aconteceu reveste-se, claramente, da utilização do economic statecraft por parte da China, configurando uma verdadeira ação geoeconómica, e visando a obtenção de objetivos geopolíticos. Um dos principais objetivos foi proteger as reivindicações chinesas pela soberania territorial em torno das Ilhas Diaoyu, a que o Japão chama Ilhas Senkaku.

As Ilhas Senkaku foram formalmente reclamadas pelo Japão em 1895 (com exceção de um breve período depois da II Guerra Mundial quando os EUA exerceram controlo sobre o território), e foram detidas por cidadãos (privados) japoneses ao longo de mais de 100 anos. A China começou a reclamar a posse das Ilhas Senkaku nos anos 1970, invocando direitos históricos. As tensões reacenderam-se em 2012, quando o Japão comprou três ilhas a um dono privado. As ilhas revestem-se de uma importância significativa, do ponto de vista económico, já que detém reservas potenciais de petróleo e gás natural, estão perto de importantes rotas marítimas e estão rodeadas por zonas dotadas de vastos recursos piscícolas (Council of Foreign Relations, 2021). Cada um dos países reclama direitos económicos numa zona económica exclusiva de 200 milhas náuticas da respetiva costa, existindo uma zona de sobreposição.

Para além do intuito de desenvolver as reservas de petróleo e gás natural que existem em redor das Ilhas, as reivindicações chinesas revestem-se de uma luta pela honra e poder regional, de modo a enfraquecer a aliança entre Tóquio e Washington. Ao longo da primeira década do século XXI, os conflitos entre a China e o Japão foram frequentes, tendo a China por diversas vezes perturbado os fluxos comerciais com o Japão, entre disputas políticas. Outras medidas foram também tomadas, como inspeções agressivas às importações 
de pescado provenientes do Japão, um pedido às empresas japonesas para não participarem na feira de Chengdu, capital da província de Sichuan, e desencorajamento aos turistas chineses em visitarem o Japão, com repercussões significativas sobre a evolução da economia nipónica (Blackwill \& Harris, 2016).

Pequim tem também utilizado a regulação dos fluxos comerciais de commodities para influenciar ações em torno das disputas territoriais relacionadas com as Ilhas Senkaku/Diaoyu. Em 2010, um barco pesqueiro chinês colidiu com dois navios da guarda costeira japonesa, perto das ilhas em disputa. O capitão chinês foi preso pelos militares japoneses e, em retaliação, a China bloqueou a exportação de óxidos de terras raras e metais puros para o Japão. Esses materiais eram componentes fundamentais para as indústrias japonesas e de manufatura. Sem eles, o Japão não consegue produzir os componentes elétricos requeridos pelas empresas norte-americanas e europeias. Esta iniciativa geoeconómica chinesa, com implicações significativas nas cadeias globais de valor, terá contribuído para a decisão japonesa de libertar o comandante do navio chinês. No ano seguinte, a China voltou a flectir o seu músculo geoeconómico, para induzir as empresas estrangeiras que dependam de terras raras a mover os seus centros de produção e tecnologia para a China, em troca do fornecimento de terras raras a baixo custo (Kalantzakos, 2020).

Empresas japonesas como a Hitachi Metals e a Toyota relocalizaram fábricas na China, o que foi ao encontro dos objetivos estratégicos chineses de desenvolver a indústria de terras raras. O caso da Hitachi Metal é muito interessante, já que evidencia a reação às medidas desencadeadas pelas autoridades chinesas. Embora a China tenha exercido uma pressão semelhante sobre outros países, como Taiwan ou Coreia do Norte, a ação sobre o Japão é mais assertiva, dado tratar-se do principal aliado dos EUA na região. E enfatiza ainda mais a importância das ações geoeconómicas, neste caso veiculada a partir da arbitrariedade do sistema regulatório chinês, em detrimento dos meios militares. E o resultado foi bastante satisfatório: a China enviou um forte sinal às pretensões territoriais japonesas, garantiu a libertação do capitão chinês e consolidou a sua quota de mercado, ao obrigar empresas japonesas a relocalizar a sua produção na China, alavancando a sua capacidade de traduzir o domínio das cadeiras de valor em poder geopolítico. Ao mesmo tempo, a China mostra ao mundo que já não tem receio de afrontar um dos principais aliados dos EUA, estendendo a estes últimos o impacto das sanções geoeconómicas. E os EUA mostraram também estarem mais dependentes de embargos de terras raras do que o próprio Japão, principalmente a nível do setor de defesa. Dois anos mais tarde, o Japão comprou 3 das ilhas a uma família japonesa, que as detinha desde os anos 1970, ricas em recursos da pesca e potenciais reservas 
de gás. Os cidadãos chineses manifestaram-se ruidosamente contra essa compra, forçando ao encerramento de fábricas automóveis japonesas na China, e prosseguindo com o boicote a vários produtos nipónicos. As exportações japonesas para a China caíram quase 15\% em 2012. A China reforçou a sua atuação geoeconómica, diminuindo o número de licenças para a mineração de terras raras em mais de $40 \%$.

Adicionalmente, os produtores chineses substituíram os fornecedores japoneses por sul coreanos. E surgiram apelos a que a China utilizasse o seu poder como maior credor do Japão para impor sanções ao comportamento japonês, desencadeando uma crise fiscal. Apareceram também apelos a que a China invocasse a cláusula de isenção de segurança para impor sanções económicas ao Japão. No entanto, os consumidores chineses acabaram por sofrer o impacto das sanções, traduzindo ao mesmo tempo a predisposição para suportar os custos dos mecanismos retaliatórios das medidas geoeconómicas.

No entanto, o Japão retaliou, levando mesmo alguns peritos a afirmar que a coerção económica se tornou contraprodutiva nas disputas marítimas chinesas. Em resposta à pressão económica e aos boicotes dos consumidores, o Japão recusou recuar no caso das ilhas disputadas, fortalecendo antes a cooperação com outros vizinhos asiáticos, incluindo a Índia e o Vietname, ao mesmo tempo que aumentava a ajuda a vários países na orla do Pacífico, nomeadamente as 13 ilhas que constituem o Fórum (Blackwill \& Harris, 2016).

O Japão, aliado com os EUA, Canadá e a União Europeia, levou o caso a um tribunal internacional, argumentando que a China estava violar as regras da $\mathrm{OMC}$, com as suas restrições à exportação, que eram incompatíveis com o que estava previsto no Protocolo de Adesão, já que não faziam parte das exceções previstas no Anexo 6. No entanto, Pequim argumentou que as restrições eram necessárias para proteger as pessoas e o ambiente da poluição associada ao processo de extração, que iria ser aumentada se se mantivesse o volume de produção. E invocou o Artigo XX ( $g$ ) do GATT - 1994, de conservação de recursos naturais não renováveis. O Painel concluiu que a China estava a aplicar medidas que configuravam uma política industrial bem definida, que visava o controlo do mercado de um recurso específico, e que, por isso, não se enquadrava totalmente numa política de proteção ambiental, obrigando a China a retirar as quotas e o embargo.

Depois desse acontecimento, o Japão avançou decisivamente para garantir a segurança no abastecimento de terras raras: em 2011, a empresa Japan Oil Gas and Metals National Corporation (JOGMEC), fundada em 2004, e com a missão explícita de garantir um aprovisionamento estável de recursos minerais (petróleo, gás, metais, entre outros), apoiada pelo Estado, e a Sojitz, uma em- 
presa de trading, anunciaram empréstimos e participação no capital no valor de 250 milhões de dólares na australiana Lynas, uma empresa mineradora de terras raras, em troca do fornecimento ao Japão de 8500 toneladas de terras raras em cada ano, 30\% da procura total nipónica.

A empresa Lynas é a única produtora com escala suficiente para a separação de terras raras a operar fora da China, e a segunda maior empresa do mundo neste sector. Os seus depósitos estão situados em Mount Weld, na Austrália Ocidental, operando a maior empresa de processamento de terras raras do mundo, na Malásia.

O apoio do Japão à Lynas é considerado genericamente um sucesso. Mas esta estratégia acarreta riscos. Depois da China retomar as exportações e os preços das terras baixarem drasticamente, a Lynas entrou numa situação de eminente colapso. Em 2016, a JOGMEC e a Sojitz acordaram em reestruturar a dívida da empresa, recuperando a fábrica de processamento da Lynas, na Malásia. A estratégia japonesa é globalmente considerada bem-sucedida, já que, atualmente, as iniciativas desenvolvidas conseguem suprir cerca de $1 / 3 \mathrm{da}$ procura japonesa por terras raras.

\section{0 caso da Magnequench e a posterior reorientação das políticas industrial e comercial}

A China também tentou exercer a sua influência, como grande fornecedora de terras raras, sobre os EUA, nomeadamente sobre a sua indústria de defesa e o acesso à tecnologia. O caso da Magnequench é particularmente significativo.

A Magnequench era uma subsidiária da General Motors norte-americana, com tecnologia exclusive na produção de imãs de grande potência, que utilizavam neodímio como elemento base, muito utilizados na produção de airbags e sensores mecânicos para automóveis e da indústria de defesa norte-americana. A Magnequench foi, no entanto, vendida pela GM aquando do processo de reestruturação desta última no início dos anos 1990, por não ser considerada como parte das competências centrais da empresa. A empresa foi colocada no mercado, e foi adquirida em 1995 por um consórcio de que faziam parte duas SOE chinesas, a San Huan New Material e a China National Nonferrous Metals Import and Export Company, que procuravam adquirir a empresa desde o início da década de 1980. Detendo a maior parte das ações da Magnequench, as empresas chinesas rapidamente violaram o acordo que tinham estabelecido com o Committee on Foreign Investment in the United States (CFIUS), de manter a fábrica a funcionar nos EUA por um período de 10 anos. Assim que dominaram a tecnologia utilizada pela empresa, fecharam as instalações da mesma no estado do Indiana, passando para a China a produção de componentes essen- 
ciais à sua indústria de defesa. No final da década, em 1998, a Agência Norte Americana do Ambiente (EPA) obrigou a empresa Molycorps, principal fornecedora de óxidos de terras raras à Magnequench, a fechar a sua mina de Mountain Pass, a segunda maior mina do mundo de terras raras, com uma refinaria associada. Isto retirou do mercado $20 \%$ de produtos de terras raras, colocando em dificuldades várias empresas, mas não a Magnequench, detida pelo Estado chinês, e que agora tinha todas as condições para desenvolver a sua produção na China, e consolidar o seu monopólio (Hurst, 2010; Tkacik, 2008).

Como referimos acima, a mina de Mountain Pass, a única mina norte-americana de terras raras, foi fechada, primeiro por razões ambientais e, posteriormente, em 2015, pela incapacidade de competir com as suas congéneres chinesas, dada a quebra no preço das terras raras. No entanto, um novo capítulo foi iniciado em 2017, quando a mina foi comprada pela empresa $M P$ Materials, sedeada em Las Vegas, e dedicada à exploração de terras raras. Com a reabertura da mina de Mountain Pass, a produção global de terras raras por parte da China passou de mais de 95\% em 2010 para 70\% em 2018, e deverá baixar ainda mais, tendo os EUA declarado que iriam apoiar outros países a desenvolver as suas reservas. Refira-se que a mina de Mountain Pass é detida maioritariamente por hedge funds, mas conta igualmente com $8 \%$ do seu capital nas mãos da Shenghe Resources, uma empresa detida parcialmente pelo Estado chinês. Com subsídios concedidos pelo governo norte-americano, pelo departamento de defesa, a empresa prevê construir novas instalações para processar as terras raras, numa tentativa de reduzir a dependência dos fornecimentos chineses. No entanto, o único cliente da Mountain Pass é a China, para onde a empresa envia todo o seu output para processamento...

Apesar de todos os esforços, em 2018, os EUA ainda importavam da China 80\% das suas necessidades de terras raras (o Japão, 58\%, e a União Europeia, 56\%) (CSIS, 2021), sem que se vislumbrem fontes alternativas acessíveis, e a indústria tem uma dimensão suficientemente pequena para que a China consiga condicionar as importações provenientes de outros países para os EUA.

É interessante constatar que, também no contexto da mais recente guerra comercial entre os dois países, houve um retrocesso por parte da Administração Trump na aplicação de sanções: inicialmente, as terras raras foram incluídas na lista de produtos chineses sujeitos a sanções, nomeadamente a aplicação de tarifas sobre as importações, numa altura em que os EUA importavam, como vimos acima, quase $80 \%$ das terras raras processadas da China. A aplicação das tarifas iria ter, estimou-se na altura, consequências dramáticas sobre as indústrias de alta tecnologia norte-americanas, pelo que as terras raras acabaram por ser removidas da lista de produtos sujeitos a 
sanções em setembro de 2018 (Kalantzakos, 2020), ao mesmo que assinava uma Ordem Executiva que declarava uma emergência nacional na indústria de mineração, dada a dependência da China. Mais tarde, aquando do zénite da guerra comercial com os EUA, em 2019, Xi Jinping visitou a Província de Jiangxi, conhecida pela abundância de terras raras, trazendo novamente à lembrança o embargo que a China decretou às exportações de terras raras em 2010, que praticamente suspendeu várias cadeias de produção japonesas. As ações e declarações de Xi Jinping recordaram aos EUA e aos seus aliados que estar profundamente dependente da China para ter acesso às terras raras é uma vulnerabilidade estratégica, que pode ser explorada em caso de conflito. Finalmente, em fevereiro de 2021, o Presidente Joe Biden emitiu uma ordem executiva para aferir da sustentabilidade das cadeias de valor que são de importância estratégica para a segurança económica e nacional, incluindo os minerais críticos e a produção de baterias.

\section{Perspetivas}

Atualmente, a China ainda continua a controlar a grande maioria da mineração e processamento de terras raras, a nível global. Desde o final dos anos 1980, como referido acima, a China empenhou-se em construir um monopólio de exploração e processamento de terras raras, implementando um conjunto de medidas: proibiu as empresas estrangeiras de participar em qualquer etapa da cadeia de valor, se não estivessem associadas em joint ventures com empresas chinesas; introduziu quotas de produção e exportação para empresas domésticas e em joint ventures com empresas estrangeiras; promoveu a fusão de várias empresas numa única, banindo novas licenças de exportação; implementou um sistema de preços rigidamente controlado. Para além das implicações económicas, o monopólio conferia à China uma alavancagem muito grande, no sentido de pressionar ou sancionar outros países

Naturalmente, a China utiliza o quase monopólio que detém na mineração e processamento de terras raras e a importância das mesmas nas cadeias de valor para exercer uma pressão geopolítica sobre os seus rivais.

Um aspeto interessante, é que as diferentes economias são motivadas por preocupações distintas, que refletem a heterogeneidade nos seus perfis de dotação fatorial e nas estruturas industriais. Os EUA parecem mais preocupados com uma dependência de importações que pode ser explorada sob o ponto de vista geopolítico, enquanto a União Europeia e o Japão estão mais preocupados com os efeitos que uma disrupção das cadeias de valor pode ter sobre a competitividade das respetivas indústrias (Nakano, 2021). Perseguindo estes objetivos, os EUA investem no desenvolvimento das suas capacidades mids- 
tream, e a União Europeia apoia a indústria de produção de baterias. A China transferiu o controlo da matéria-prima para o domínio de outras etapas da cadeia, com maior valor incorporado: transformar óxidos em metal e metal em produtos. Ampliando a comparação de Deng, é como se o Médio Oriente não só detivesse o petróleo, mas que o refinasse e fizesse produtos a partir daí (The Economist, 2019). Atualmente, e na sequência das tensões dos últimos anos, o Ministério chinês da Indústria e Tecnologias da Informação (MIIT), fez sair, em Janeiro deste ano, um conjunto de Regulamentos sobre a Gestão das Terras Raras, que envolve um controle mais apertado da indústria no país, incluindo normas de proteção ambiental, quotas para as várias fases da cadeia de valor, considerando que as terras raras são de insubstituível significado para a transformação das indústrias tradicionais e para o desenvolvimento da defesa nacional, ciência e tecnologia, o que revela claramente a intenção do governo de centralizar o controlo sobre toda a cadeia de valor (Chen, 2021). A posição da China nestas cadeias não é totalmente segura, já que vários países, com reservas abundantes (Brasil, Vietname, Rússia) começaram a desenvolver tentativas para explorar a mineração e o processamento, e tanto os EUA como a Austrália aumentaram a sua produção ao longo dos últimos 10 anos. Em 2018, a China tornou-se mesmo um importador líquido de terras raras, já que o desenvolvimento das suas indústrias de alta tecnologia (com destaque para o Made in China 2025 e o Plano Quinquenal 2021-2025), assim como vários projetos no âmbito da própria Belt and Road Initiative, associados ao desmantelamento de muita atividade ilegal, ultrapassaram a escala doméstica de produção.

É por esta razão que as terras raras são utilizadas na guerra comercial. Os EUA conseguem complicar o funcionamento das empresas chinesas impedindo as empresas americanas de lhes vender componentes, como os semicondutores. Mas a China consegue retaliar, bloqueando as exportações de terras raras ou derivados, nomeadamente os imãs especializados que são utilizados nos motores dos veículos elétricos, geradores em turbinas eólicas ou sistema de orientação de mísseis. Até o Pentágono é um cliente desses imãs, como vimos no caso da Magnequench.

Onde a China tem maior alavancagem é nas fases posteriores da cadeia, pois já não é o país caracterizado exclusivamente por atividades de mineração ou montagem, mas consolida-se como detendo uma indústria transformadora de elevado valor acrescentado, que requer um volume cada vez maior de minerais e metais que são críticos para essa indústria. Ou seja, está a reforçar a sua posição nos segmentos a jusante da cadeia de valor. Esta modificação do perfil de especialização da economia chinesa também levou a que outras 
economias que dependem da importação desses minerais tenham envidado esforços para garantir a segurança das respetivas cadeias de valor, com destaque para os EUA e Japão, principais importadores das terras raras com origem na China. E a procura dessas terras raras não cessa de aumentar, prevendo-se que se intensifique no futuro. No entanto, o problema não se resume às terras raras: em 2050, de acordo com o Banco Mundial, a manterem-se as metas assumidas no Acordo de Paris, a produção de cobalto, grafite e lítio teria de ser $450 \%$ mais elevada do que em 2018, para responder à procura de baterias, o que significa um reforço significativo do investimento em novas minas. Estima-se também que mais de 3 mil milhões de toneladas de minerais e metais serão necessários para gerar energia eólica, solar e geotermal, para conseguir reduzir a temperatura global em 2 graus Celsius (Banco Mundial, 2020).

Os acontecimentos mais recentes têm, no entanto, realçado a dimensão geopolítica que caracteriza a sequência de ações no setor das terras raras, evidenciando, novamente, a sua dimensão crítica para a segurança económica e nacional dos vários países ou blocos. A título de exemplo, citamos as recentes restrições (Novembro de 2021) impostas pelo Japão aos investimentos estrangeiros em setores que envolvem terras raras, com a inclusão de um conjunto de metais de terras raras na lista de setores onde as intenções de investimento estrangeiro devem ser previamente objeto de escrutínio e autorização governamental, ao abrigo do Foreign Exchange and Foreign Act, de forma a assegurar um abastecimento estável dos referidos elementos (Investment Policy Monitor - UNCTAD, 2021).

Por seu turno, os EUA prosseguem igualmente uma política de salvaguarda dos seus interesses estratégicos em relação à sustentabilidade dos metais de terras raras, particularmente no que respeita ao setor da defesa, com o Departamento de Defesa a investir na construção de fábricas de separação de terras raras, na Califórnia e no Texas, em colaboração com a empresa australiana de separação de terras raras, Lynas. Para tal, foi acionado o Defense Production Act, que concede uma autorização presidencial para expandir a produção doméstica para abastecimento de minerais de importância crítica destinados à defesa nacional. Estas medidas, assim como o acordo assinado com o Canadá para o estabelecimento de uma cadeia de valor resiliente na América do Norte para minerais críticos, inserem-se na ordem executiva 14017, de junho de 2021, em que são definidas medidas para reduzir a dependência dos EUA de fornecimentos de países potencialmente hostis, em áreas consideradas vitais para a segurança dos EUA, como os semicondutores, baterias, minerais críticos e produtos farmacêuticos (The White House, 2021). A via escolhida assenta no apoio maciço do governo ao estabelecimento de cadeias de valor resilientes, baseadas 
na indústria norte-americana e na dos aliados dos EUA, sendo o fator crítico de sucesso a capacidade e o potencial de inovação tecnológica, nomeadamente no que respeita à substituição de elementos de terras raras por outros existentes em maior abundância (o caso dos imãs é o mais relevante), ou incentivando à reciclagem dos materiais usados, de modo a reduzir a necessidade de novas importações, no contexto da economia circular (Hall, 2021).

É igualmente importante salientar que, embora os estudos de caso apresentados tenham incidido sobre as terras raras e os seus produtos derivados, os receios de disrupção das cadeias de valor, agravando a dependência de fornecimento de materiais críticos por parte de países hostis ou rivais, não se restringem ao setor das terras raras. Tal ficou bastante claro com a produção de equipamento médico indispensável para o combate à pandemia, assim como de semicondutores. Efetivamente, a pandemia de Covid-19 tornou evidente a fragilidade das cadeias globais de valor, para equipamentos médicos, vacinas e medicamentos, em grande medida em consequência dos embargos impostos por vários países.

A confluência de todos estes acontecimentos aumentou a importância estratégica de garantir a segurança das cadeias globais de valor, especialmente para as economias mais inovadoras ou com forte indústria transformadora e de alta tecnologia, especialmente em setores onde se perspetiva um substancial aumento da procura (energias limpas, defesa, inteligência artificial), onde as preocupações de natureza geopolítica assumem um crescente protagonismo como forma de manter ou conquistar poder no contexto global.

Data de receção: 19/07/2021

Data de aprovação: 17/12/2021

\section{Referências}

Adamas Intelligence. (2019). Rare Earth elements: Small Markets, Big Necessity. Retrieved junho 2021, from https://www.adamasintel.com/report/rare-earth-elements-small-market-big-necessity/

Banco Mundial. (2020). Minerals for Climate Action: The Mineral Intensity of the Clean Energy Transition. Washington. Retrieved junho 2021, from https://www. worldbank.org/en/topic/extractiveindustries/brief/climate-smart-mining-minerals-for-climate-action\#: :text=A\%20new\%20World\%20Bank\%20 Group\%2oreport\%2C\%20\%22Minerals\%2ofor,meet $\% 20$ the $\% 20$ growing\%20demand\%2ofor\%20clean\%2oenergy\%2otechnologies

Baru, S. (2012). Geoeconomics and Strategy. Survival, 54(3), 47-58. doi: https://doi.or $\mathrm{g} / 10.1080 / 00396338.2012 .690978$ 
Bergeijk, P. v., Putten, F.-P. v., Rood, J., \& Meijnders, M. (2015). Geopolitics and economic vulnerability. The Hague: Clingendael Monitor - Netherlands Institute of International Relations. Retrieved maio 2021, from https://www.clingendael.org/ sites/default/files/pdfs/3_geopolitics_and_economic_vulnerability.pdf

Blackwill, R., \& Harris, J. (2016). War by Other Means - Geoeconomics and Statecraft. Cambridge: Harvard University Press - Belknap Press.

Bryant, G. (2015). Examining Perspectives on China's Near Monopoly of Rare Earths. Florida: FIU Electronic Theses and Dissertations 1845. Retrieved dezembro 2021, from https://digitalcommons.fiu.edu/etd/1845

Chen, E. (2021). Directions Forward for Chinese Rare Earths After the Two Sessions. The China Brief - Journal of Analysis and Information, 21(5), 1-5. Retrieved from https://jamestown.org/program/directions-forward-for-chinese-rareearths-after-the-two-sessions/

Council of Foreign Relations. (2021, junho). https://www.cfr.org/chinas-maritime-disputes/\#!/chinas-maritime-disputes?cid=otr-marketing_use-china_sea_InfoGuide. Retrieved from https://www.cfr.org/.

CSIS. (2021). Does China Pose a Threat to Global Rare Earth Supply Chains? China Power Team - Centre for Strategic International Studies. Retrieved from https://chinapower.csis.org/china-rare-earths/

Csurgai, G. (2018). The Increasing Importance of Geoeconomics in Power Rivalries in the Twenty-First Century. Geopolitics, 23(1), 38-46.

Ganguli, R., \& Cook, D. (2018). Rare earths: A review of the landscape. MRS Energy $\&$ Sustainability: A Review Journal, 1-16. doi:doi:10.1557/mre.2018.7

Global Atlas of Environmental Justice. (2020, agosto 4). https://ejatlas.org/conflict/ bayan-obo-world-biggest-rare-earths-mine-baogang-group-baotou-inner-mongolia-china. Retrieved from EJAtlas - Global Atlas of Environmental Justice.

Hall, M. (2021, june 14). Made in Australia: Why is the Pentagon investing in Australian rare earths? Mining Technology. Retrieved dezembro 2021, from https:// www.mining-technology.com/features/made-in-australia-why-is-the-pentagon-investing-in-australian-rare-earths/

Harris, R. B. (2016). War by Other Means.

Higgins, R. (2015). The strategic and security implications of rare earths. In R. Higgins, The Political Economy of rare earth elements (pp. 1-19). New York: Palgrave Macmillan.

Hitachi Metals Ltd. (2016). Notice Concerning Establishment of Neodymium-Iron-Boron Magnet Joint Venture (Subsidiary Transfer) in china. Retrieved junho 2021, from https://www.hitachi-metals.co.jp/e/ir/ir-news/20160902en.pdf

Hurst, C. (2010). China's Rare Earth Elements Industry: What Can the West Learn? Kansas, USA: Institute for the Analysis of Global Security (IAGS). Retrieved junho 2019, from http://www.iags.org/rareeartho310hurst.pdf

Information Office of the State Council - PRC. (2010). Situation and Policies of China's Rare Earth Industry. Beijing. Retrieved dezembro 2021, from http://english. www.gov.cn/archive/white_paper/2014/08/23/content_281474983043156.htm

Investment Policy Monitor - UNCTAD. (2021, novembro). Foreign investment in activities related to 34 rare-earth metals now subject to screening. Retrieved from 
UNCTAD - United Nations Conference on Trade and Development: https:// investmentpolicy.unctad.org/investment-policy-monitor/measures/3760/ japan-foreign-investment-in-activities-related-to-34-rare-earth-metals-nowsubject-to-screening

Kalantzakos, S. (2018). China and the Geopolitics of the Rare Earths. Oxford: Oxford University Press. doi:DOI: 10.1093/oso/9780190670931.001.0001

Kalantzakos, S. (2020, julho). The Race for Critical Minerals in an Era of Geopolitical Realigments. The International Spectator - Italian Journal of International Affairs, 55(3), 1-16. doi:https://doi.org/10.1080/03932729.2020.1786926

Kim, D. (2019). The Perils of Geoeconomics. The Washington Quarterly, 42(1), 153-170. doi:https://doi.org/10.1080/0163660X.2019.1593666

Leonard, M. (2016). Connectivity Wars - Why Migration, Finance and Trade are the Geoeconomics Battlegrounds of the Future. (M. Leonard, Ed.) European Council on Foreign Affairs, 224. Retrieved from https://www.files.ethz.ch/ isn/195852/Connectivity_Wars.pdf

Lorot, P. (1999). Introduction à la Géoeconomie. Paris: Economica.

Lovins, A. (2017, maio 23). https://thebulletin.org/2017/05/clean-energy-and-rare-earthswhy-not-to-worry/. Retrieved junho 2021, from https://thebulletin.org/.

Luttwak, E. (1990). From Geopolitics to Geoeconomics: Logic of conflict, Grammar of Commerce. (C. f. Interest, Ed.) The National Interest, Summer(20), 17-22.

Luttwak, E. (1993). The Endangered American Dream . Nova Iorque: Simon \& Schuster.

Mancheri, N., Sundaresan, L., \& Chandrashekar, S. (2013). Dominanting the world: China and the reare earth industry. (I. S. Programme, Ed.) Bangalore, India: National Institute of Advanced Studies. Retrieved from https://www.researchgate.net/publication/313477894_Dominating_the_World_China_and_ the_Rare_Earth_Industry

Nakano, J. (2021). The Geopolitics of Critical Minerals Supply Chains. Center for Strategic and International Studies - CSIS. Retrieved junho 2021, from https:// www.csis.org/analysis/geopolitics-critical-minerals-supply-chains

Nanto, D. (2011). Economics and National Security: Issues and Implications for U.S. Policy. Congressional Research Service. Retrieved maio 2021, from https://www. fas.org/sgp/crs/natsec/R41589.pdf

Overland, I. (2019). The geopolitics of renewable energy: Debunking four emerging myths. Energy Research \& Social Science (49), 36-40. doi:https://doi.org/10.1016/j. erss.2018.10.018

Pollins, B. (1989). Does Trade Still Follow the Flag? American Political Science Review, 83(2), 465-480. doi:DOI: https://doi.org/10.2307/1962400

Ronis, S. (2011). Economic Security - Neglected Dimension of National Security? Washington: Washington, Center for Strategic Conferencing - Institute for National Strategic Studies . Retrieved from http://ndupress.ndu.edu/Portals/68/ Documents/Books/economic-security.pdf

Seaman, J. (2019). Rare Earths and China - a Review of Changing Critically in the New Economy. IFRI. Paris: Notes de l'IFRI. Retrieved junho 2019, from https:// www.ifri.org/en/publications/notes-de-lifri/rare-earths-and-china-review-changing-criticality-new-economy 
Shen, Y., Moomy, R., \& Eggert, R. G. (2020). China's public policies toward rare earths, 1975-2018. Mineral Economics (33), 127-151. doi:https://doi.org/10.1007/ s13563-019-00214-2

Smith, R. (2012). China's Rare Earth Policies: Economic Statecraft or Interdependence? Master Thesis, Naval Postgraduate School, Monterey. Retrieved maio 2021, from https://ia803006.us.archive.org/26/items/chinasrareearthp1094527906/ chinasrareearthp1094527906.pdf

Stratfor. (2019, abril 8). The Geopolitics of Rare Earths. Retrieved junho 2021, from Stratfor Worldview: https://worldview.stratfor.com/article/geopolitics-rare-earth-elements

Tabeta, S. (2021, outubro 2021). Retrieved from Nikkei Asia: https://asia.nikkei.com/ Economy/China-to-create-rare-earths-giant-by-joining-three-state-companies

The Economist. (2019, junho 15). The Economist. Retrieved from https:/www.economist.com/china/2019/06/15/rare-earths-give-china-leverage-in-the-tradewar-at-a-cost

The White House. (2021). Building resilient supply chains, revitalizing American manufacturing and ofstering broad based growth. Retrieved dezembro 2021, from https://www.whitehouse.gov/wp-content/uploads/2021/06/100-day-supplychain-review-report.pdf

Tkacik., J. (2008, maio 2). https://www.heritage.org/. Retrieved from https://www. heritage.org/asia/report/magnequench-cfius-and-chinas-thirst-us-defensetechnology

Tse, P.-K. (2011). China's rare-earth industry. Virginia: US Geological Service. Retrieved junho 2021, from https://pubs.usgs.gov/of/2011/1042/of2011-1042.pdf

UNCTAD. (2014). Commodities at a Glance - Special Issue on Rare Earths. Nova Iorque e Genebra: United Nations Conference on Trade and Development - UNCTAD. Retrieved junho 2021, from https://unctad.org/system/files/official-document/suc2014d1_en.pdf

Uren, D. (2019). A quest for global dominance: China's appetite for rare earths. Retrieved junho 2021, from https://www.aspistrategist.org.au/a-quest-for-global-dominance-chinas-appetite-for-rare-earths/

USGS. (2021). Mineral Commodities Summary. US Geological Service. Retrieved maio 2021, from https://pubs.usgs.gov/periodicals/mcs2021/mcs2021-rare-earths. pdf

Wiggell, M. (2015). Conceptualizing regional powers' geoeconomic strategies: neo-imperialism, neo-mercantilism, hegemony, and liberal institutionalism. Asia Europe Journal, 14, 135-151. doi:DOI 10.1007/s10308-015-0442-X

Wübbeke, J. (2013). Rare earthelements in China:Policies and narratives of reinventing an industry. Resource Policy, 38, 384-394. doi:https://doi.org/10.1016/j. resourpol.2013.05.005

Wubekke, J. (2013, setembro). Rare earth elements in China: policies and narratives of reinventing an industry. Resource Policy, 38(3), pp. 384-394. doi:https://doi. org/10.1016/j.resourpol.2013.05.005 
Wubekke, J. (2015). China's rare earth industry and end-use: supply security and innovation. In R. Higgins, The political economy of rare earth elements (pp. 20-42). New York: Palgrave Macmillan.

\section{Sobre a autora}

CARLA GUAPO COSTA é Professora no Instituto Superior de Ciências Sociais e Políticas (ISCSP), da Universidade de Lisboa (UTL), e doutora em Economia pelo Instituto Superior de Economia e Gestão (ISEG), da mesma Universidade. É também Auditora de Defesa Nacional e Investigadora do Instituto do Oriente e as suas principais áreas de investigação centram-se, genericamente, na geoeconomia e economia política. É autora de vários artigos científicos e livros sobre as áreas acima referidas. Participa atualmente em missões de consultoria e formação em países de expressão oficial portuguesa, em Angola, São Tomé e Príncipe e Timor-Leste.

[ORCID ID: https://orcid.org/oooo-00o2-6091-6649]

\section{About the author}

CARLA GUAPO COSTA is a Professor at the School of Social and Political Sciences (ISCSP), of the University of Lisbon. She holds a PhD in Economics, and a Degree on National Defense Auditing. She is also a researcher at Instituto do Oriente, of ISCSP. She is the author of several papers and books on geoeconomics and international political economy, European Union economics and great players geoeconomic strategies. She is currently participating in consulting and human capital building in Portuguese speaking countries, in Southern Africa and East Timor.

[ORCID ID: https://orcid.org/oooo-0002-6091-6649] 